\title{
PERAN DUKUNGAN SOSIAL BAGI KESEJAHTERAAN PSIKOLOGIS FAMILY CAREGIVER ORANG DENGAN SKIZOFRENIA (ODS) RAWAT JALAN
}

\author{
Atikah Amalia $^{\left.1^{\star}\right)}$, Rina Rahmatika ${ }^{1}$ \\ ${ }^{1}$ Fakultas Psikologi, Universitas Yarsi, Jakarta 10560, Indonesia \\ *)Email: atkamliaa@gmail.com
}

\begin{abstract}
Abstrak
Ketidakmampuan memenuhi fungsi secara optimal merupakan tantangan yang harus dihadapi oleh family caregiver dalam melakukan perawatan pada pasien orang dengan skizofrenia (ODS) sehingga dibutuhkan dukungan sosial yang dapat meningkatkan kesejahteraan psikologis dari family caregiver ODS. Tujuan dari penelitian ini adalah untuk menganalisis peranan dari dukungan sosial terhadap kesejahteraan psikologis family caregiver ODS rawat jalan. Penelitian ini menggunakan pendekatan kuantitatif dengan teknik pemilihan contoh menggunakan non-probability purposive sampling. Sampel dalam penelitian ini berjumlah 57 partisipan. Data penelitian dikumpulkan dengan kuesioner multidimensional perceived social support (ó =0,659-0,757) dan Ryff Psychological well-being (á=0,855-0,914) yang telah disesuaikan dengan subjek penelitian. Dukungan sosial diukur dari persepsi partisipan tentang dukungan sosial yang diperoleh. Hasil penelitian menunjukkan bahwa dimensi friends berperan signifikan terhadap dimensi personal growth, positive relationship, dan purpose in life dari kesejahteraan psikologis family caregiver ODS; sementara dimensi family berperan terhadap dimensi environtmental mastery. Hasil penelitian juga menemukan bahwa dimensi significant others tidak berperan signifikan terhadap semua dimensi dari kesejahteraan psikologis family caregiver ODS. Berdasarkan hasil penelitian, dukungan sosial yang dipersepsikan oleh family caregiver ODS rawat jalan berperan penting karena dapat meningkatkan kesejahteraan psikologisnya. Hal ini akan dapat mengoptimalkan perawatan yang diberikan oleh family caregiver yang akan berdampak pada proses pemulihan dari anggota keluarga yang mengalami skizofrenia.
\end{abstract}

Kata kunci: family caregiver, kesejahteraan psikologis, perceived social support, rawat jalan, skizofenia

\section{The Role of Social Support for the Psychological Well-Being of Family Caregivers of Outpatients with Schizophrenia}

\begin{abstract}
The inability to fulfill functions optimally is a challenge that must be faced by family caregivers in treating patients with schizophrenia so that social support is needed to improve the psychological well-being of ODS family caregivers. The purpose of this study was to analyze the role of social support on the psychological well-being of family caregivers of patients with schizophrenia. This study used a quantitative approach with a sampling technique using non-probability purposive sampling. The sample in this study amounted to 57 participants. The research data were collected using a questionnaire of Multidimensional perceived social support (á $=0,659-0,757)$ and Ryff Psychological well-being (á=0,855-0,914) which were adjusted to the research subject. Social support is measured by the participants' perceptions about the social support they get. The results showed that the dimensions of friends played a significant role in the dimensions of personal growth, positive relationships, and purpose in the life of the psychological well-being of family caregivers; while the family dimension plays a role in the environmental dimension of mastery. The results also found that the significant other dimension did not play a significant role in all dimensions of the psychological well-being of the family caregiver. Based on the results of the study, perceived social support plays an important role in family caregivers because it can improve their psychological well-being. It will optimize the care provided by the family caregiver that will have an impact on the recovery process of family members who have schizophrenia.
\end{abstract}

Keywords: family caregiver, outpatients, perceived social support, psychological well-being, schizophenia

\section{PENDAHULUAN}

Skizofrenia adalah penyakit kronis berupa gangguan mental yang serius dan ditandai dengan adanya gangguan dalam proses berpikir sehingga dapat memengaruhi perilaku individu dalam menjalankan fungsinya (Thorson, Matson, Rojahn, \& Dixon, 2008). 
Berdasarkan data WHO (2015), prevalensi orang dengan skizofrenia (ODS) berjumlah 26 juta penderita di seluruh dunia, sedangkan di Indonesia prevalensi ODS sekitar 1-2 persen penduduk atau berjumlah 2-4 juta jiwa (Kemenkes, 2016). Selain kota-kota tersebut, ODS juga ditemukan di kota Jakarta dengan prevalensi 187 orang pada tahun 2016; meningkat menjadi 203 orang pada tahun 2017 dan pada Juli 2018 telah mencapai 227 orang (Hidayat, 2019). Dengan demikian, dapat disimpulkan bahwa prevalensi ODS di Jakarta mengalami peningkatan setiap tahunnya.

Pengetahuan terkait perawatan ODS belum sepenuhnya dipahami oleh masyarakat secara luas. ODS dianggap sebagai seseorang yang bodoh dan aneh dan dapat membahayakan sehingga sebagian besar ODS tidak dibawa berobat, melainkan disembunyikan atau bahkan diperiksakan ke pengobatan supranatural (Rahmawati, Widiyanti, \& Sajodin, 2018). Berdasarkan hasil Riset Kesehatan Dasar (Kemenkes, 2016) sebesar 31,5 persen pasien skizofrenia di Indonesia dipasung dirumah. Pemasungan dilakukan agar ODS tidak membahayakan orang-orang yang ada di sekitarnya dan menimpakan aib bagi keluarga (Poegoeh \& Hamidah, 2016). Berdasarkan hasil penelitian yang dilakukan oleh Hardiyanti, Usman, dan Yusuf (2015), keluarga terpaksa melakukan pemasungan karena menganggap bahwa apabila ODS tidak dipasung maka keluarga tidak akan bisa bekerja dan hanya menghabiskan waktu untuk merawat pasien. Selain itu, peneliti juga mendapatkan data awal melalui proses wawancara kepada salah satu keluarga pasien yang berinisial $R$ bahwa keluarga pasien $R$ memasung pasien selama kurang lebih 2 tahun dengan cara mengikat tangan dan kaki pasien menggunakan tali. Keluarga mengatakan bahwa mereka terpaksa melakukan hal tersebut karena kondisi pasien yang jika dilepaskan ikatannya akan mengganggu tetangga di sekitar rumah. Misalnya saja, pasien menggunakan palang untuk menghalangi warga yang akan melewati gerbang perumahan tempat pasien tinggal dan beberapa kali pasien juga mengaji di atas atap tetangganya.

Menurut Dominguez, Viechtbauer, Simons, Van, dan Krabbendam (2009), ODS mengalami gejala positif dan juga gejala negatif. Gejala positif dan gejala negatif yang dialami oleh penderita skizofrenia mengakibatkan penderita mengalami kendala atau hambatan yang nyata pada kemampuan fungsional dalam berbagai bidang misalnya pekerjaan, hubungan sosial, kemampuan merawat diri, dan bidang lainnya, yang selanjutnya akan menimbulkan kesulitan dalam kehidupan pribadi, keluarga, maupun kehidupan sosial. Oleh karena itu, ODS cenderung menggantungkan sebagian besar aspek kehidupan mereka kepada pihak lain yaitu keluarga atau relasi dari penderita skizofrenia (Suaidy, 2006).

Keluarga sebagai family caregiver memiliki peranan penting dalam kesembuhan ODS (Vania \& Dewi, 2014). Family caregiver adalah jenis caregiver informal yang merawat penderita setiap harinya tanpa menerima bayaran (Fatimah, Ahmad, \& Efri, 2018). Keluarga atau relasi sebagai sistem pendukung utama seringkali mengalami beban yang tidak ringan dalam memberikan perawatan kepada pasien ODS selama dirawat di rumah sakit maupun setelah kembali ke rumah (Suryenti, 2017).

ODS yang telah kembali ke rumah (rawat jalan) seringkali justru menimbulkan masalah dan beban bagi family caregiver. Permasalahan yang dihadapi tidak hanya biaya pengobatan yang memang relatif tinggi, beban lain yaitu kesehatan fisik dan mental caregiver dalam memberikan perawatan dan pengawasan bagi anggota keluarga yang menderita skizofrenia. Perawatan dan pengawasan yang dilakukan dapat mencapai 24 jam sehari (Ambarsari \& Puspitasari, 2012). Schulz dan Sherwood (2008) mengatakan bahwa proses pendampingan dalam jangka waktu yang panjang dapat menyebabkan pengalaman stres yang kronis serta menimbulkan ketegangan fisik serta psikologis. Selain itu, hasil penelitian di Kanada menyebutkan bahwa anggota keluarga secara signifikan tertekan karena memiliki keluarga dengan skizofrenia (Martens \& Adington, 2001). Family caregiver juga mengalami beban subjektif seperti merasakan ketidaknyamanan dari adanya pandangan yang kurang menyenangkan dari masyarakat dikarenakan mempunyai anggota keluarga dengan gangguan mental (Suryenti, 2017).

Beban yang dialami oleh keluarga sebagai family caregiver menjadi salah satu permasalahan global saat ini (Dewi \& Marquez, 2017) dan beban tersebut berada di tingkat menengah sampai tinggi (Pun, He, \& Wang, 2014). Beban dan masalah yang dimiliki keluarga sebagai caregiver akan mengakibatkan diri caregiver tidak dapat memenuhi fungsi dirinya secara optimum sehingga hal ini berkaitan dengan kesejahteraan psikologisnya. Keluarga mengalami kejenuhan dalam merawat pasien, keletihan yang mendalam, menurunnya minat 
hidup, menurunnya harga diri, dan kehilangan empati terhadap ODS (Suaidy, 2006). Pernyataan tersebut sejalan dengan hasil penelitian Nainggolan dan Hidajat (2013) yang menemukan bahwa kesejahteraan psikologis dari family caregiver belum terpenuhi secara optimal. Padahal, dengan adanya kondisi sejahtera pada diri individu dapat membuat individu bertahan dari kesulitan yang sedang dihadapi (Vania \& Dewi, 2014). Selain itu, Fan dan Lu (2020) menyebutkan bahwa adanya dukungan sosial dapat memberikan kontribusi terhadap kesejahteraan pada diri individu. Psychological well-being merupakan komponen penting dalam subjective-wellbeing dan keduanya memiliki hubungan yang positif signifikan. Oleh karena itu, kesejahteraan psikologis dari family caregiver dianggap sebagai hal yang perlu diperhatikan karena apabila kesejahteraan psikologis dari family caregiver menurun maka perawatan yang diberikan kepada ODS rawat jalan akan menjadi tidak optimal.

Menurut Ryff dan Singer (2008), terdapat dua faktor yang memengaruhi kesejahteraan psikologis yaitu faktor psikososial dan faktor demografis. Faktor psikososial berkaitan dengan regulasi emosi, kepribadian, tujuan pribadi, nilai, strategi koping, dan spiritualitas. Sementara itu, faktor demografis berkaitan dengan usia, jenis kelamin, dan status sosial ekonomi. Selain kedua faktor tersebut, Ryff juga menyebutkan bahwa salah satu faktor penting yang dapat memengaruhi kesejahteraan psikologis adalah dukungan sosial (Ryff \& Singer, 2008).

Pentingnya pemberian dukungan sosial kepada keluarga sebagai family caregiver dibuktikan dengan hasil penelitian yang telah dilakukan sebelumnya yang menyebutkan bahwa family caregiver dalam merawat anggota keluarganya yang skizofrenia memerlukan adanya dukungan sosial dari masyarakat sekitar (Putri, Machmuroh, \& Astriani, 2016). Dengan adanya dukungan sosial, keluarga dapat meningkatkan fungsinya dan membantu pemulihan dari anggota keluarga yang mengalami gangguan skizofrenia. Sementara itu, tidak adanya dukungan sosial dikaitkan dengan munculnya gangguan fungsi dan peningkatan gejala psikiatri serta berkurangnya potensi untuk berintegrasi di dalam masyarakat secara optimal (McCorkle, Rogers, Dunn, Lyass, \& Wan, 2004). Nainggolan dan Hidayati (2013) menyebutkan bahwa dengan adanya dukungan sosial bagi keluarga yang tengah mengalami krisis secara umum dapat meningkatkan kesejahteraan psikologis dan kualitas kehidupan keluarga. Hal ini diperkuat dengan hasil penelitian sebelumnya yang menyebutkan bahwa terdapat hubungan yang positif signifikan antara pemberian dukungan sosial terhadap kesejahteraan psikologis dari family caregiver ODS (Vania \& Dewi, 2014).

Dukungan sosial terbagi menjadi dua yaitu dukungan sosial yang dipersepsikan (perceived social support) dan dukungan sosial yang diterima (received social support) (Young, 2006). Received social support adalah jenis dukungan yang benar-benar diberikan oleh individu, sedangkan perceived social support adalah keyakinan individu mengenai adanya dukungan sosial yang tersedia ketika individu membutuhkannya (Barrera, Irwin, \& Thomas, 1981). Received social support digunakan untuk mengukur seberapa besar dukungan yang diterima oleh individu dari jaringan sosialnya, sedangkan perceived social support digunakan untuk mengukur persepsi individu yang menerima bantuan secara keseluruhan terhadap dukungan yang diberikan oleh jaringan sosialnya (Haber, Cohen, Lucas, \& Baltes, 2007).

Penelitian ini akan fokus pada perceived social support karena menurut Cohen dan Wills (1985) dukungan sosial yang dipersepsikan berhubungan positif dengan kesejahteraan psikologis. Hasil penelitian tersebut sejalan dengan penelitian yang dilakukan oleh Major, Zubek, Cooper, Cozzarelli, dan Richards (1997) yang menyebutkan bahwa persepsi seseorang terhadap adanya dukungan sosial yang diterima dapat membuat kondisi kesejahteraan psikologis menjadi lebih baik. Selain itu, hasil penelitian Lee, Ybarra, Gonzalez dan Ellsworth (2017) menyebutkan bahwa semakin banyak dukungan sosial yang dipersepsikan oleh caregiver skizofrenia dalam suatu krisis maka akan semakin baik pula kondisi kesehatan mentalnya. Hal tersebut akan berdampak positif pada kondisi kesejahteraan psikologis dari caregiver ODS.

Berdasarkan penelitian serupa yang dilakukan oleh Vania dan Dewi (2014), dukungan sosial memiliki peranan yang signifikan dalam kesejahteraan psikologis family caregiver dari ODS, namun penelitian ini tidak memberikan spesifikasi terhadap partisipan penelitian seperti yang akan dilakukan peneliti dalam penelitian ini. Penelitian ini akan spesifik terhadap family caregiver dari ODS rawat jalan saja. Penelitian yang dilakukan sebelumnya hanya menganalisis peranan antara variabel dukungan sosial dan kesejahteraan psikologis secara menyeluruh sedangkan tujuan dalam 
penelitian ini adalah menganalisis salah satu jenis dukungan saja yaitu perceived social support dan akan menganalisis peran masingmasing dimensi secara terpisah terhadap kesejahteraan psikologis family caregiver ODS rawat jalan.

\section{METODE PENELITIAN}

Penelitian ini menggunakan pendekatan kuantitatif dengan tipe pengujian korelasional. Partisipan penelitian berjumlah 57 family caregiver dari ODS rawat jalan. Teknik pengambilan contoh dalam penelitian ini menggunakan purposive sampling dengan karakteristik contoh yaitu: family caregiver dari ODS rawat jalan, tinggal bersama ODS dalam satu rumah, bersedia menjadi partisipan dari penelitian, mengetahui informasi mengenai gangguan yang diderita oleh anggota keluarga yang mengalami skizofenia. Pengambilan data dilakukan di dua tempat, yaitu RSJ Marzoeki Mahdi Bogor dan KPSI (Komunitas Peduli Skizofrenia Indonesia) Jatinegara. Proses pengambilan data dilakukan secara online dan offline. Secara online digunakan google form dan secara offline dilakukan dengan memberikan kuesioner secara langsung kepada family caregiver ODS rawat jalan di lokasi pengambilan data.

perceived social support adalah persepsi individu akan dukungan yang dapat diperoleh pada saat individu sedang berada dalam suatu situasi sulit dan pada umumnya dukungan ini bersifat subjektif. Tipe dukungan ini disusun berdasarkan tiga dimensi yaitu keluarga, teman, dan significant others (Zimet, Dahlem, Zimet, \& Farley, 1988). Semakin tinggi skor rata-rata pada masing-masing dimensi dari perceived social support yang diperoleh subjek menunjukkan semakin tinggi perceived social support pada dimensi tersebut dan sebaliknya.

Pada penelitian ini, variabel perceived social support diukur menggunakan Multidimensional perceived social support (MPSS) yang mengacu pada Zimet et al. (1988). Multidimensional perceived social support terdiri dari 12 butir pernyataan. Ada lima rentang pilihan jawaban dari angka $1 \quad(1=$ Sangat Tidak Setuju, 2=Tidak Setuju, 3=Agak Tidak Setuju, 4=Netral, 5=Agak Setuju). Alat ukur ini terdiri dari pernyataan favourable dan tidak memiliki pernyataan non favourable. Alat ukur MPSS memiliki nilai reliabilitas sebesar $0,855-0,914$. Selain itu, uji validitas internal juga menunjukkan hasil positif karena memiliki nilai corrected item-total correlation di atas 0,2 , yaitu berkisar antara 0,623-0,882 (Nisfiannoor, 2009).

Kesejahteraan psikologis diartikan sebagai kebahagiaan, yang berarti individu merasakan kebebasan dari distres yang dicerminkan oleh adanya keseimbangan antara aspek positif dan aspek negatif (Diener \& Larsen, 1993). Menurut Ryff (1995) psychological well-being adalah keadaan saat individu bukan hanya terbebas dari tekanan atau permasalahan mental saja, tetapi juga mampu menerima dirinya sendiri maupun kehidupan masa lalunya (selfacceptance), pengembangan diri atau pertumbuhan diri (personal growth), keyakinan bahwa hidupnya memiliki makna dan tujuan (purpose in life), memiliki kualitas yang positif dalam berhubungan dengan orang lain (positive relations with others), memiliki kapasitas untuk mengatur hidup dan lingkungannya (environtmental mastery), serta kemampuan untuk menentukan kehidupannya sendiri (autonomy).

Alat ukur kesejahteraan psikologis menggunakan Ryff's Psychological well-being 42 item version yang mengacu pada Ryff (1989). Alat ukur ini memiliki skala 1-6 sebagai alternatif jawaban, dengan skor 1 (sangat tidak setuju), 2 (tidak setuju), 3 (sedikit tidak setuju), 4 (sedikit setuju), 5 (setuju) dan 6(sangat setuju). Pada alat ukur ini terdapat beberapa pernyataan unfavourable, yang cara penilaiannya adalah dengan membalik skor (1 menjadi 6, 5 menjadi 2, dan begitu seterusnya), begitupun sebaliknya ( 6 menjadi 1, 2 menjadi 5 dan begitu seterusnya). Hasil uji reliabitas dan validitas menunjukkan bahwa alat ukur Ryff's Psychological well-being memiliki nilai reliabilitas yang baik, yaitu berkisar antara 0,659-0,757. Namun, alat ukur Ryff's Psychological well-being, 42 item version juga memiliki nilai yang kurang baik karena beberapa pernyataan memiliki nilai corrected item-total correlation di bawah 0,2, yang berkisar antara 0,076-0,629. Selanjutnya, data dianalisis dengan menggunakan SPSS (V.22.0; IBM Corp, Armonk, New York, USA). Analisis yang dilakukan terkait dengan data informasi umum dan khusus dari partisipan, uji normalitas, uji linearitas dan uji regresi ganda secara parsial.

\section{HASIL}

\section{Data Informasi Umum dan Khusus dari Partisipan Penelitian}

Jumlah subjek dalam penelitian ini sebanyak 57 partisipan. Berdasarkan usia, mayoritas family 
caregiver $(50,87 \%)$ berusia $40-65$ tahun dan juga didominasi oleh subjek yang berjenis kelamin perempuan (59,64\%). Lebih dari setengah $(57,89 \%)$ subjek berdomisili di Jabodetabek. Selain itu, suku terbanyak dari family caregiver ODS rawat jalan adalah Suku Jawa (64,91\%). Rata-rata subjek dalam penelitian ini sudah menikah $(69,84 \%)$. Hampir sepertiga $(29,82 \%)$ pendidikan terakhir subjek berada pada jenjang S1 dan berstatus tidak bekerja $(30,15 \%)$. Persentase penghasilan tertinggi dari subjek penelitian ini adalah Rp1.000.000,00 - Rp5.000.000,00 per bulan $(63,51 \%)$. Jumlah anggota keluarga terbanyak yang tinggal bersama dengan subjek adalah lima orang dalam satu rumah $(84,21 \%)$.

Berdasarkan data khusus dari partisipan penelitian, persentase tertinggi dari lamanya merawat pasien ODS yang telah dilakukan oleh family caregiver adalah lima tahun (36,84\%). Jenis skizofrenia yang diderita oleh ODS rawat jalan pada penelitian ini didominasi oleh jenis skizofrenia paranoid $(59,64 \%)$. Hasil penelitian juga menunjukkan bahwa sebesar 63,15 persen terdapat anggota keluarga lainnya yang mengalami gangguan skizofrenia. Selain itu, sebesar 59,64 persen family caregiver memiliki anggota keluarga lainnya yang membantu dalam perawatan ODS. Persentase anggota keluarga lain yang ikut membantu dalam merawat ODS adalah keluarga besar $(35,08 \%)$. Selain anggota keluarga, sebesar 52,63 persen family caregiver juga mendapatkan bantuan dari orang di luar keluarga yang ikut membantu merawat ODS. Kebanyakan dari orang di luar keluarga yang ikut membantu adalah teman $(31,57 \%)$. Hasil penelitian menunjukkan bahwa sebagian besar bentuk bantuan yang diberikan oleh orang di luar keluarga adalah berupa dukungan instrumental $(70,17 \%)$.

Hasil lain juga menunjukkan bahwa sebesar 55,38 persen family caregiver dari penelitian ini mempunyai kebutuhan yang spesifik dalam melakukan perawatan terhadap ODS. Berdasarkan hasil riset, kebutuhan paling banyak dalam melakukan perawatan ODS adalah waktu, biaya dan kesabaran $(31,57 \%)$. Selanjutnya, sebesar 96,50 persen family caregiver dalam penelitian ini memiliki harapan kepada anggota keluarganya yang mengalami gangguan skizofrenia, yaitu harapan agar anggota keluarganya lekas sembuh (40,35\%). Selain itu, sebesar 84,21 persen family caregiver dari ODS tidak mengalami gangguan kesehatan kronis dan juga sebesar 66,67 persen family caregiver memiliki asuransi kesehatan.
Tabel 1 Hasil uji normalitas

\begin{tabular}{|c|c|}
\hline \multirow{2}{*}{$\begin{array}{c}\text { Dimensi psychological well } \\
\text { being } 42 \text { item }\end{array}$} & $\begin{array}{l}\text { Dimensi perceived } \\
\text { social support }\end{array}$ \\
\hline & $\begin{array}{c}\text { Keluarga, teman } \\
\text { dan significant } \\
\text { others }\end{array}$ \\
\hline Autonomy & $0,167^{\star}$ \\
\hline Environtmental mastery & $0,200^{*}$ \\
\hline Personal growth & $0,200^{*}$ \\
\hline Purpose in life & $0,200^{*}$ \\
\hline Self acceptance & $0,200^{*}$ \\
\hline Positive relationship & $0,200^{\star}$ \\
\hline
\end{tabular}

Keterangan: $\mathrm{N}=57,{ }^{*}=$ significant, $\mathrm{SO}=$ Significant Others

Hasil yang tersaji pada Tabel 1 menunjukkan bahwa data pada penelitian ini berdistribusi secara normal karena setiap dimensi-dimensi pada variabel perceived social support memiliki nilai signifikansi $p>0,05$ terhadap dimensidimensi pada kesejahteraan psikologis. Dengan demikian, data residual berdistribusi normal dan telah memenuhi asumsi normalitas.

\section{Peranan Perceived Social Support terhadap Kesejahteraan Psikologis}

Hasil yang tersaji pada Tabel 2 menunjukkan bahwa dimensi-dimensi pada perceived social support yang berperan secara parsial (secara terpisah) terhadap dimensi-dimensi pada kesejahteraan psikologis, yaitu: (i) dimensi family pada perceived social support berperan terhadap dimensi environtmental mastery; (ii) dimensi friends pada perceived social support berperan terhadap dimensi personal growth, positive relationship; dan (iii) dimensi friends pada perceived social support juga berperan terhadap dimensi purpose in life pada kesejahteraan psikologis.

Dilihat dari peranan secara parsial, dimensi friends adalah dimensi yang memiliki peranan paling besar dari variabel perceived social support terhadap dimensi positive relationship pada kesejahteraan psikologis $(p=0,001$ dan $R 2=36,5)$. Hal ini bermakna, dengan adanya persepsi mengenai dukungan sosial yang bersumber dari teman maka kemampuan untuk membangun hubungan positif dengan orang lain dari family caregiver akan semakin baik. Di lain sisi, dimensi family adalah dimensi yang memiliki peranan paling lemah dari variabel perceived social support terhadap dimensi environmental mastery pada variabel kesejahteraan psikologis $(p=0,04$ dan $\mathrm{R} 2=17,1)$. 
Tabel 2 Hasil uji regresi ganda parsial

\begin{tabular}{|c|c|c|c|c|c|c|c|c|c|c|c|c|c|c|c|c|c|c|}
\hline \multirow{3}{*}{$\begin{array}{c}\text { Dime } \\
\text { nsi } \\
\text { perc } \\
\text { eived } \\
\text { socia } \\
\text { I } \\
\text { supp } \\
\text { ort }\end{array}$} & \multicolumn{18}{|c|}{ Dimensi psychological well being 42 item } \\
\hline & \multicolumn{3}{|c|}{ Autonomy } & \multicolumn{3}{|c|}{$\begin{array}{l}\text { Environtmental } \\
\text { mastery }\end{array}$} & \multicolumn{3}{|c|}{$\begin{array}{l}\text { Personal } \\
\text { growth }\end{array}$} & \multicolumn{3}{|c|}{ Purpose in life } & \multicolumn{3}{|c|}{$\begin{array}{c}\text { Self } \\
\text { acceptance }\end{array}$} & \multicolumn{3}{|c|}{$\begin{array}{c}\text { Positive } \\
\text { relationship }\end{array}$} \\
\hline & Sig & $\mathrm{t}$ & $\mathrm{R} 2$ & Sig & $\mathrm{t}$ & $\mathrm{R} 2$ & Sig & $\mathrm{t}$ & $\mathrm{R} 2$ & Sig & $\mathrm{t}$ & $\mathrm{R} 2$ & Sig & $\mathrm{t}$ & $\mathrm{R} 2$ & Sig & $\mathrm{t}$ & $\mathrm{R} 2$ \\
\hline Family & $\begin{array}{r}0,9 \\
94\end{array}$ & $\begin{array}{r}0, \overline{0} \\
08\end{array}$ & $\begin{array}{r}0,1 \\
15\end{array}$ & $\begin{array}{l}0,0 \\
47^{*}\end{array}$ & $\begin{array}{r}2,0 \\
29\end{array}$ & $\begin{array}{l}0,2 \\
51\end{array}$ & $\begin{array}{r}0,3 \\
63\end{array}$ & $\begin{array}{r}0,9 \\
18\end{array}$ & $\begin{array}{r}0,1 \\
67\end{array}$ & $\begin{array}{l}0,1 \\
55\end{array}$ & $\begin{array}{r}1,4 \\
44\end{array}$ & $\begin{array}{r}0,2 \\
26\end{array}$ & $\begin{array}{l}0,1 \\
04\end{array}$ & $\begin{array}{l}1,6 \\
56\end{array}$ & $\begin{array}{r}0,3 \\
10\end{array}$ & $\begin{array}{r}0,2 \\
32\end{array}$ & $\begin{array}{r}1,2 \\
09\end{array}$ & $\begin{array}{r}0,3 \\
01\end{array}$ \\
\hline $\begin{array}{l}\text { Friend } \\
s\end{array}$ & $\begin{array}{r}0,1 \\
80\end{array}$ & $\begin{array}{l}1,3 \\
60\end{array}$ & $\begin{array}{r}0,1 \\
45\end{array}$ & $\begin{array}{r}0,1 \\
92\end{array}$ & $\begin{array}{l}1,3 \\
21\end{array}$ & 0 & $\begin{array}{l}0,0 \\
35^{*}\end{array}$ & $\begin{array}{r}2,1 \\
62\end{array}$ & $\begin{array}{r}0,2 \\
34\end{array}$ & $\begin{array}{l}0,0 \\
01^{*}\end{array}$ & $\begin{array}{r}3,4 \\
11\end{array}$ & $\begin{array}{r}0,3 \\
65\end{array}$ & $\begin{array}{l}0,0 \\
33^{*}\end{array}$ & $\begin{array}{r}2,1 \\
84\end{array}$ & $\begin{array}{r}0,3 \\
67\end{array}$ & $\begin{array}{r}0,3 \\
32\end{array}$ & $\begin{array}{r}0,9 \\
80\end{array}$ & 0 \\
\hline $\begin{array}{l}\text { Signifi } \\
\text { cant } \\
\text { others }\end{array}$ & $\begin{array}{l}0,3 \\
73\end{array}$ & $\begin{array}{r}0,8 \\
99\end{array}$ & $\begin{array}{r}0,1 \\
14\end{array}$ & $\begin{array}{r}0,5 \\
07\end{array}$ & $\begin{array}{r}0,6 \\
68\end{array}$ & $\begin{array}{l}0,1 \\
71\end{array}$ & $\begin{array}{r}0,8 \\
18\end{array}$ & $\begin{array}{r}0,2 \\
31\end{array}$ & $\begin{array}{r}0,1 \\
35\end{array}$ & $\begin{array}{r}0,6 \\
61\end{array}$ & $\begin{array}{r}0,4 \\
11\end{array}$ & $\begin{array}{r}0,1 \\
61\end{array}$ & $\begin{array}{r}0,3 \\
34\end{array}$ & $\begin{array}{r}0,9 \\
54\end{array}$ & $\begin{array}{r}0,2 \\
50\end{array}$ & $\begin{array}{r}0,0 \\
52\end{array}$ & $\begin{array}{r}1,9 \\
86\end{array}$ & $\begin{array}{r}0,2 \\
73\end{array}$ \\
\hline
\end{tabular}

Keterangan: $\mathrm{N}=$ jumlah partisipan (57 orang); ${ }^{*}=$ signifikan

Peran Dimensi Family pada Perceived Social Support terhadap Kesejahteraan Psikologis

Hasil penelitian menunjukkan bahwa dimensi family berperan terhadap dimensi environmental mastery $(\mathrm{R} 2=17,1)$. Artinya, subjek penelitian yang memiliki keluarga ODS rawat jalan memersepsikan adanya dukungan sosial yang berasal dari keluarga sehingga membentuk aspek penguasaan lingkungan. Individu yang memiliki aspek penguasaan lingkungan ditandai dengan adanya kemampuan untuk mengendalikan lingkungan eksternal di lingkungannya termasuk mengatur dan mengendalikan aktivitas sehari-hari, memanfaatkan kesempatan yang ada di lingkungan, serta mampu memilih dan menciptakan lingkungan yang sesuai dengan kebutuhan dan nilai-nilai pribadi. Untuk menumbuhkan aspek penguasaan lingkungan, dibutuhkan pula lingkungan yang mendukung. Lingkungan tersebut dimulai dari adanya lingkungan keluarga yang dapat membantu individu untuk membentuk pengendalian lingkungan eksternalnya.

Dukungan sosial dari keluarga memiliki peranan penting dalam pembentukan aspek penguasaan lingkungan pada kesejahteraan psikologis. Keluarga merupakan lingkungan terdekat dari subjek penelitian yang diharapkan dapat membantu dalam perawatan anggota keluarga yang mengalami gangguan skizofrenia. Dengan adanya dukungan sosial yang berasal dari keluarga dapat membentuk persepsi subjek penelitian mengenai dukungan sosial yang berasal dari keluarga. Hal tersebut akan dapat membentuk aspek penguasaan lingkungan dari subjek penelitian. Temuan ini juga didukung oleh data demografis yang menunjukkan bahwa mayoritas dari family caregiver mendapatkan bantuan dari anggota keluarga lain dalam merawat anggota keluarga yang mengalami gangguan jiwa dengan persentase sebesar 59,64 persen. Dengan demikian, perceived social support yang berasal dari keluarga dapat berperan secara signifikan terhadap penguasaan lingkungan dari subjek penelitian ini.

Peran dimensi friends pada perceived social support terhadap kesejahteraan psikologis. Hasil penelitian menunjukkan bahwa dimensi friends memiliki peranan yang cukup besar terhadap dimensi positive relationship dari kesejahteraan psikologis $(\mathrm{R} 2=36,5)$. Artinya, subjek penelitian yang memiliki keluarga ODS memersepsikan adanya dukungan sosial yang berasal dari teman, sehingga membentuk aspek hubungan positif.

Selain itu, dimensi friends pada perceived social support juga berperan terhadap dimensi purpose in life pada kesejahteraan psikologis $(\mathrm{R} 2=36,7)$. Artinya, subjek penelitian yang memiliki keluarga ODS rawat jalan memersepsikan adanya dukungan sosial yang berasal dari teman sehingga membentuk aspek tujuan hidup. Arti hidup dan tercapainya target yang diinginkan dalam kehidupan berhubungan dengan adanya harapan seseorang. Dengan adanya harapan maka individu memiliki motivasi untuk mencapai apa yang diharapkan. Motivasi tersebut akan membuat individu berupaya untuk mencapai target dalam hidupnya. Pada penelitian ini, family caregiver mayoritas memiliki harapan kepada anggota keluarganya yang ODS terutama agar lekas sembuh serta beraktivitas kembali dengan normal. Berdasarkan informasi sosiodemografi, family caregiver banyak menerima bantuan seperti uang dan kendaraan untuk berobat. Selain itu, family caregiver juga mendapat bantuan dari teman $(40,35 \%)$ berupa paparan 
informasi mengenai obat, psikolog, dan ahli psikiater. Berbagai bantuan tersebut menurut peneliti berkaitan dengan usaha penyembuhan yang sejalan dengan harapan family caregiver. Hal ini memungkinkan peranan perceived social support dari teman menjadi signifikan terhadap tujuan hidup family caregiver dalam penelitian ini.

Hasil penelitian ini juga menemukan bahwa dimensi friends berperan terhadap dimensi personal growth pada kesejahteraan psikologis $(\mathrm{R} 2=36,7)$. Artinya, subjek penelitian yang memiliki keluarga ODS rawat jalan memersepsikan adanya dukungan sosial yang berasal dari teman sehingga membentuk aspek pertumbuhan pribadi. Dukungan suportif dari teman dapat membuat subjek penelitian meyakini bahwa dirinya tidak sendirian dan tidak dikucilkan sehingga hal tersebut dapat membuat subjek berpersepsi bahwa teman dapat memberikan dukungan sosial pada saat dibutuhkan.

Selanjutnya, berdasarkan hasil wawancara terhadap subjek penelitian family caregiver yang berjenis kelamin perempuan, mereka lebih banyak bergabung dengan komunitas skizofrenia untuk berbagi pengalaman dan melakukan sharing dengan caregiver lainnya mengenai perawatan dan penanganan anggota keluarga yang mengalami skizofrenia dibandingkan family caregiver yang berjenis kelamin laki-laki. Asumsi-asumsi tersebut memungkinkan perceived social support yang berasal dari teman dapat berperan secara signifikan terhadap perkembangan pribadi dari subjek penelitian ini.

\section{PEMBAHASAN}

Berdasarkan analisis data terdapat beberapa dimensi pada perceived social support yang berperan signifikan terhadap beberapa dimensi dari kesejahteraan psikologis. Peranan dari masing-masing dimensi tersebut adalah dimensi friends pada perceived social support yang berperan terhadap beberapa dimensi pada kesejahteraan psikologis, yaitu dimensi positive relationship, purpose in life, dan personal growth. Sementara itu, dimensi family pada perceived social support hanya berperan signifikan terhadap satu dimensi dari kesejahteraan psikologis yaitu dimensi environmental mastery. Di lain sisi, dimensi significant others pada perceived social support tidak berperan terhadap semua dimensi dari kesejahteraan psikologis. Selain itu, dalam penelitian ini ditemukan bahwa dimensi-dimensi pada perceived social support tidak berperan terhadap dimensi autonomy dan self acceptance dari family caregiver ODS rawat jalan.

Adapun dimensi yang tidak berkontribusi secara signifikan adalah dimensi significant others pada perceived social support yang secara konsisten tidak ditemukan adanya signifikansi terhadap semua dimensi dari kesejahteraan psikologis. Hal ini didukung oleh hasil penelitian yang dilakukan oleh Wijayanti, Sunarti, dan Krisnatuti (2020), yang menyebutkan bahwa teman dan keluarga memang memiliki kontribusi paling optimal dalam memberikan dukungan sosial terhadap anggota keluarganya. Artinya, meskipun terdapat persepsi mengenai dukungan sosial yang bersumber dari significant others tidak dapat membentuk aspek-aspek dalam kesejahteraan psikologis dari family caregiver ODS rawat jalan. Namun, temuan dari penelitian ini tidak sejalan dengan hasil penelitian yang dilakukan oleh Aydin, Kahraman, dan Hicdurmaz (2017) yang mana hal ini disebabkan karena perbedaan subjek yang digunakan dalam penelitian.

Lebih lanjut, hasil kajian memperlihatkan bahwa ODS rawat jalan mampu memersepsikan dukungan sosial yang berasal dari keluarga sehingga mereka akan membentuk aspek penguasaan lingkungan. Lingkungan yang dimaksud yaitu lingkungan keluarga yang dapat membantu subjek untuk membentuk pengendalian lingkungan eksternalnya. Adapun penguasaan lingkungan yang baik ditandai dengan adanya perasaan kompeten dalam menguasai lingkungan serta dapat memilih atau menciptakan lingkungan yang cocok untuk dirinya (Harimukthi \& Dewi, 2014). Dukungan sosial dari keluarga memiliki peranan penting dalam pembentukan aspek penguasaan lingkungan pada kesejahteraan psikologis. Hal ini dikarenakan antaranggota keluarga memiliki hubungan interpersonal yang telah lama dibangun (Rahma \& Rahayu, 2018). Selain itu, pasien ODS juga mampu memersepsikan dukungan sosial yang berasal dari teman. Dukungan sosial ini akan membentuk aspek hubungan yang positif. Individu yang memiliki aspek hubungan positif dengan orang lain dapat membangun hubungan yang hangat dan penuh kepercayaan. Individu tersebut juga akan memiliki rasa kepedulian terhadap kesejahteraan orang lain, dapat menunjukkan empati, afeksi serta memiliki prinsip memberi dan menerima dalam suatu hubungan (Ryff, 1995). Adanya aspek hubungan positif dengan orang lain yang terbentuk dari subjek penelitian sejalan dengan adanya hasil penelitian yang 
dilakukan oleh Garcia, Soriano, dan Arrianza (2014), yang menyebutkan bahwa keterikatan dengan teman berkaitan dengan emosi positif yang dapat membentuk hubungan positif dalam hubungan pertemanan. Emosi positif berkaitan dengan adanya empati dan afeksi dalam suatu hubungan, yang menandakan bahwa terdapat indikasi dari adanya aspek hubungan positif dengan orang lain (Syarifah, 2018).

Pada saat individu memiliki emosi positif dalam suatu hubungan maka individu tersebut juga akan memiliki pemikiran yang positif pula terhadap orang lain. Hal tersebut akan memengaruhi persepsinya terhadap adanya dukungan sosial yang akan ia terima ketika membutuhkannya. Selain itu, berdasarkan hasil penelitian Yunita (2014) menunjukkan bahwa gender dapat memengaruhi pembentukan hubungan yang positif. Perempuan memiliki keterbukaan diri yang lebih tinggi dibandingkan dengan laki-laki. Ketika memiliki masalah, perempuan cenderung akan lebih mudah untuk membuka dirinya mengenai masalah yang dihadapi sehingga akan terbentuk rasa percaya terhadap teman. Rasa percaya tersebut membuat subjek penelitian memiliki persepsi bahwa teman adalah sumber dukungan sosial yang dapat dicari saat dibutuhkan.

Selanjutnya, subjek dalam penelitian ini memersepsikan adanya dukungan sosial yang berasal dari teman sehingga membentuk aspek tujuan hidup. Individu yang memiliki aspek tujuan hidup akan memiliki arah hidup yang jelas, mampu merasakan arti dari pengalaman hidup di masa lalu dan masa kini serta memiliki tujuan dan target yang ingin di capai dalam kehidupannya (Ryff, 1995). Arti hidup dan tercapainya target yang diinginkan dalam kehidupan berhubungan dengan adanya harapan seseorang. Hal ini dibuktikan pada hasil penelitian yang dilakukan oleh Wnuk, Marcinkowski, dan Fobair (2012) yang menyatakan bahwa tujuan hidup berhubungan positif dengan harapan.

Hasil riset memperlihatkan, family caregiver yang berjenis kelamin perempuan lebih banyak bergabung dengan komunitas skizofrenia untuk berbagi pengalaman dengan caregiver lainnya. Asumsi-asumsi tersebut memungkinkan perceived social support yang berasal dari teman dapat berperan secara signifikan terhadap perkembangan pribadi dari subjek penelitian ini. Hasil penelitian yang dilakukan oleh Luawo dan Noor (2017) menjelaskan bahwa gender dapat memengaruhi perkembangan pribadi individu. $\mathrm{Hal}$ ini disebabkan karena perempuan memiliki kemampuan yang lebih baik dalam keterbukaan terhadap pengalaman baru dibandingkan dengan laki-laki. Individu yang memiliki perkembangan pribadi ditandai dengan pandangan bahwa dirinya adalah individu yang terus tumbuh dan berkembang, terbuka terhadap pengalaman baru, memiliki kemampuan dalam mengenali potensi diri, serta dapat berubah menjadi individu yang lebih efektif dan memiliki pengetahuan yang bertambah (Ryff, 1995). Untuk menumbuhkan keterbukaan terhadap pengalaman baru, kemampuan untuk mengenali potensi diri serta menjadi individu yang efektif membutuhkan adanya dukungan yang supportif. Hal ini dibuktikan dengan hasil penelitian yang dilakukan oleh Lee et al. (2017) yang menyebutkan bahwa dukungan supportif yang berasal dari teman dapat memungkinkan seseorang untuk bertahan dan berjuang untuk perkembangan pribadinya. Dukungan supportif dari teman dapat membuat subjek penelitian meyakini bahwa dirinya tidak sendirian dan tidak dikucilkan sehingga hal tersebut dapat membuat persepsi subjek penelitian bahwa teman juga dapat memberikan dukungan sosial pada saat dibutuhkan.

Subjek yang digunakan dalam penelitian yang dilakukan oleh Aydin et al. (2017) adalah siswa keperawatan, sedangkan subjek dalam penelitian ini adalah family caregiver dari ODS rawat jalan. Hasil penelitian yang dilakukan oleh Aydin et al. (2017) menyebutkan bahwa para siswa keperawatan memersepsikan lebih banyak mendapatkan dukungan dari significant others (pacar dan sahabat) karena para siswa keperawatan lebih banyak menghabiskan waktu mereka di asrama untuk mengerjakan tugas, baik itu tugas dalam bentuk teoritis maupun tugas praktik, sehingga dukungan sosial yang dirasakan oleh mahasiswa keperawatan adalah berupa bantuan dalam megerjakan tugas di asrama. Selain itu, hasil penelitian yang dilakukan oleh Branje, Halle, Frijins dan Meeus (2010), kebanyakan remaja lebih banyak berinteraksi dengan teman sebayanya, terutama pada remaja perempuan. Oleh karena itu, sumber dukungan sosial yang paling berperan dalam penelitian tersebut adalah significant others.

Peneliti menyadari bahwa masih terdapat banyak kekurangan dalam penelitian ini. Kekurangan tersebut antara lain adalah jumlah subjek penelitian yang sedikit yaitu 57 partisipan sehingga kemungkinan jumlah contoh dengan jumlah tersebut kurang bisa merepresentasikan kondisi family caregiver secara detail. Hal ini disebabkan karena 
sulitnya menemukan contoh sesuai dengan kriteria penelitian ini. Selain itu, peneliti juga kurang melakukan kontrol terhadap family caregiver yang memiliki anggota keluarga yang memiliki kriteria gangguan jiwa di luar dari kriteria penelitian ini. Family caregiver yang memiliki anggota keluarga yang menderita skizofenia sekaligus menderita gangguan kejiwaan lainnya. Berdasarkan data demografis, sebesar 1,75 persen family caregiver yang menjadi partisipan penelitian memiliki anggota keluarga yang mengalami gangguan skizofrenia sekaligus bipolar. Selain itu, family caregiver yang menjadi partisipan penelitian juga memiliki anggota keluarga yang mengalami gangguan skizofrenia sekaligus depresi.

\section{SIMPULAN DAN SARAN}

Hasil penelitian menunjukkan hanya perceived social support dari keluarga yang berperan signifikan terhadap environmental mastery dan dimensi perceived social support dari teman berperan signifikan terhadap personal growth, positive relationship, dan purpose in life. Sementara tidak ada peran perceived social support yang bersumber dari significant others terhadap semua dimensi kesejahteraan psikologis family caregiver ODS rawat jalan.

Berdasarkan hasil penelitian maka saran teoritis bagi peneliti adalah melakukan penelitian dengan karakteristik subjek penelitian yang serupa dengan menambah jumlahnya agar lebih merepresentasikan kondisi dari family caregiver dengan lebih mendetail. Peneliti juga perlu melakukan kontrol terhadap gangguan mental yang merupakan kriteria dari penelitian dengan difokuskan pada satu jenis gangguan saja. Selanjutnya, perlu dilakukan pertimbangan dalam melibatkan kembali dimensi penerimaan diri dan kemandirian dari kesejahteraan psikologis karena berdasarkan hasil penelitian ini sumber dukungan dari keluarga, teman, ataupun significant others tidak membentuk kedua aspek tersebut, terutama pada subjek penelitian ini yaitu family caregiver dari ODS rawat jalan. Penelitian selanjutnya yang akan melakukan penelitian dengan tema serupa, hendaknya memperhatikan pengetahuan dari family caregiver mengenai jenis dari gangguan mental yang dialami oleh anggota keluarganya, misalnya dengan cara menanyakan kepada perawat atau tenaga kesehatan lain yang bertugas atau melihat rekam medis dari anggota keluarga yang mengalami skizofrenia dari subjek penelitian.
Secara umum, hasil penelitian ini diharapkan dapat dijadikan dasar bagi institusi kesehatan untuk menekankan pentingnya dukungan sosial bagi kesejahteraan psikologis family caregiver terutama kepada family caregiver ODS rawat jalan. Beberapa program yang dapat dilakukan, diantaranya adalah sosialisasi, seminar, ataupun bakti sosial yang dapat dilakukan oleh rumah sakit, psikolog atau institusi lainnya kepada keluarga dari ODS rawat jalan mengenai pentingnya persepsi terhadap adanya dukungan sosial yang dapat memengaruhi kondisi kesejahteraan psikologis mereka dan juga perlu diberikan konsultasi terhadap anggota keluarga dari ODS rawat jalan yang merasa terbebani dalam melakukan perawatan terhadap anggota keluarganya.

\section{DAFTAR PUSTAKA}

[Kemenkes] Kementerian Kesehatan. (2016). Peran keluarga dukung kesehatan jiwa masyarakat. Jakarta, ID: Kementerian Kesehatan.

Ambarsari, R. D., \& Puspitasari, E. (2012). Penyesuaian diri caregives orang dengan skizofrenia (ODS). Jurnal Psikologika, 17(2), $\quad$ 1410-1289. doi:https://doi.org/10.20885/psikologika.vol 17.iss2.art9

Aydin, A., Kahraman, N., \& Hicdurmaz, D. (2017). Determining the perceived social support and psychological well being levels of nursing students. Journal of Pyschiatric Nursing, 8(1) 41-47. doi:10. 14744/phd.2017.95967

Branje, S. J. T., Hale III, W. W., Frijns, T., \& Meeus, W. H. J. (2010). Longitudinal Associations between perceived parentchild relationship quality and depresisive symptoms in adolescence. Journal Abnormal Child Psychology, 38(6), 751-763. doi:10.1007/s10802-010-9401-6

Cohen, S., \& Wills, T. A. (1985). Stress, social support, and the buffering hypothesis. Psychological Bulletin, 98(2), 310-357. doi:https://doi.org/10.1037/00332909.98.2.310

Dewi \& Marquez. (2017). Pengalaman caregiver dalam merawat klien skizofrenia di Kota Sungai Penuh. Journal endurance, 3(1), 200-212. doi:http://doi.org/ 10.22216/jen.v3i1.2852

Dominguez, Viechtbauer, Simons, Van, \& Krabbendam. (2009). Are psychotic psychopathology and neurocognition orthogonal? A systematic review of their 
associations. Psychol bull, 135(1), 157171. doi:10.1037/a0014415

Fan, X., \& Lu, M. (2020). Testing the effect of perceived social support on left-behind children's mental well-being in mainland China: The mediation role of resilience. Children and Youth Services Review, 109, 104-695. 2019.104695.

Fatimah, Q., Ahmad, Y., \& Efri, W. (2018). Gambaran kesejahteraan psikologis pada family caregiver orang dengan skizofrenia di instalasi rawat jalan grhaatma Bandung. Nurseline journal, 3, 20-29.

Garcia, H., Soriano, E., \& Arriaza, G. (2014). Friends with benefits and psychological wellbeing. Procedia Social and Behavioral Science, 132(2014) 241-247. doi:10.1016 /j.sbspro.2014.04.305

Haber, Cohen, Lucas, \& Baltes. (2007). The relationship between self-reported received and perceived social support: A meta-analytic review. Am J Community Psychol, 39(1-2), 133-144. doi:10.1007/ s10464-007-9100-9

Hardiyanti, D., Usman, S., Yusuf, R. (2015). Kemandirian Keluarga dalam merawat anggota keluarga yang mengalami skizofrenia. Jurnal Ilmu Keperawatan, 3(2), 172-182.

Harimukthi, M. T., \& Dewi, K. S. (2014). Eksplorasi kesejahteraan psikologis individu dewasa awal penyandang tunanetra. Jurnal Psikologi Undip, 13(1), 64-77. doi:https://doi.org /10.14710/jpu.13.1.64-77View

Hidayat, M. W. (2019). Penderita gangguan jiwa terus bertambah di Jakarta. Tempo, 14(2019)

Lee, D., Ybarra, O., Gonzalez, R., \& Ellsworth, P. (2017). I through we: How supportive social relationship facilitate personal growth. Personality and Social Psychology Bulletin, 1-12. doi:https://org/10.1177/ 0146167217730371

Luawo, M. I., \& Noor, R. (2017). Gambaran kesejahteraan psikologis pada remaja lakilaki di SMA Negeri Se-DKI Jakarta. Jurnal Bimbingan Konseling, 6(1), 50-59. doi:https://doi.org/10.21009/INSIGHT.061. 05

Major, B., Zubek, J. M., Cooper, M. L., Cozzarelli, C., \& Richards, C. (1997). Mixed messages: Implications of social conflict and social support within close relationships for adjustment to a stressful life event. Journal of Personality and Social Psychology, 72(6), 13491363. doi:https://doi.org/10.1037/00223514.72.6.1349

Martens, \& Adington. (2001). Psychological well-being of family membersof individuals with schizophrenia. Soc Psychiatry Psychiatr Epidemiol, 36(3), 128-133. doi:10.1007/s001270050301

McCorkle, Rogers, Dunn, Lyass, \& Wan. (2004). Increasing social support for individuals with serious mental illness: Evaluating the compeer model of intentional friendship. Community Mental HealthJournal, 44(5), 483-491. doi:10.1007/s10597-008-9137-8

Nainggolan, N. J., \& Hidajat, L. L. (2013). Profil kepribadian dan psychological well-being caregiver skizofrenia. Soul, 3(1), 1-6. doi:https://doi.org/10.19184/nlj.v3i1.6908

Nisfiannoor, M. (2009). Pendekatan statistika modern untuk ilmu sosial. Jakarta, ID: Salemba Humanika.

Poegoeh, D. P., \& Hamidah. (2016). Peran dukungan sosial dan regulasi emosi terhadap resiliensi keluarga penderita skizofrenia. INSAN, 1(1), 12-21. doi:http://dx.doi.org/10.20473/jpkm.V11120 16.12-21

Pun, K. K., He, G., \& Wang, X. H. (2014). Extent of Burden and coping among family caregivers living with schizophrenic patients in Nepal. International Journal of Sciences: Basic and Applied Research (IJSBAR), 35(4), 428-443. doi:10.4103/0253-7176.122224

Putri, M. A., Machmuroh, \& Astriani, S. (2016). Hubungan antara psychological well being dan dukungan sosial dengan ekspresi emosi family caregiver pasien skizofrenia dirumah sakit jiwa di Surakarta. Jurnal penelitian, 1-15.

Rahma, U., \& Rahayu, E. W. (2018). Peran dukungan sosial keluarga dalam membentuk kematangan karier siswa SMP. Jurnal IImu Keluarga dan Konsumen, 11(3), 2502-3594. doi:http//dx.doi.org/10.24156,jikk.2018.11. 3.194 .

Rahmawati, R. E., Widiyanti, A. T., \& Sajodin. (2018). Hubungan dukungan sosial dengan resiliensi caregiver penderita skizofrenia di klinik. Jurnal Keperawatan Aisyah, 71-78. 
Ryff \& Singer. (2008). Know theyself and become what you are: A eudaimonic approach to psychological well-being. Psychology, 9(1), 13-39. doi:10.1007/s10902-006-9019-0

Ryff. (1995). The structure of psychological well-being revisited. Journal of Personality and Social Psychology, 69(4), 719-727. doi:10.1037/0022-3514.69.4.719

Schulz, R., \& Sherwood, P. R. (2008). Physcal and mental health effects of family caregiving. Journal of Social Work Education, 44(3), 105-113. doi:10.5175/jswe.2008.773247702

Suaidy. (2006). Beban keluarga dengan anggota keluarga yang menderita skizofrenia. Journal of Psychology, 6(2), 110-129.

Suryenti, V. (2017). Dukungan dan beban keluarga dengan kemampuan keluarga merawat pasien resiko perilaku kekerasan di klinik jiwa rumah sakit jiwa Provinsi Jambi tahun 2017. Jurnal Psikologi Jambi, 2(2), 39-46.

Syarifah, M. (2018). Musik memiliki hubungan yang erat dengan tingkat empati seseorang. Jakarta, ID: National Geographic Indonesia

Thorson, Matson, Rojahn, \& Dixon, D. (2008). Behavior problems in institutionalized people with intellectual disability and schizophrenia spectrum disorder. Journal of Intellectual \& Developmental Disability, 33(4), 316-322. doi:10.1080/ 13668250802441649
Vania, I. W., \& Dewi, K. S. (2014). Hubungan antara dukungan sosial dengan psychologucal well-being caregiver penderita gangguan skizofrenia. Jurnal Undip, 3(4), 1-13.

Wijayanti, R., Sunarti, E., \& Krisnatuti D. (2020). Peran dukungan sosial dan interaksi ibuanak dalam meningkatkan kesejahteraan subjektif remaja pada keluarga orang tua bekerja. Jurnal ilmu Keluarga \& Konsumen, 13(2), 125-136. doi:http:/dx.doi.org/10.24156/jikk.2020.13. 2.125

Wnuk, M., Marcinkowski, J., \& Fobair, P. (2012). The relatinship of purpose in life and hope in shaping happiness among patients with cancer in Poland. Journal of Psychological Oncology, 30(4), 461- 483. doi:10.1080/07347332.2012.684988

Young, K. W. (2006). Social support and life satisfaction. International Journal of Psychosocial Rehabilitation, 10(2), 155164.

Yunita, O. (2014). Gambaran subjective wellbeing pada remaja yang tinggal di panti asuhan (Dissertation). Jawa Timur, ID: Widya Mandala Catholic University.

Zimet, G. D., Dahlem, N. W., Zimet, S. G., \& Farley, G. K. (1988). The multidimensional scale of perceived social support. Journal of Personality Assessment, 52(1), 30-41. doi:https://doi.org/10.1207/s15327752jpa5 201_2. 